\title{
Development of linear models for estimation of leaflet area in common bean (Phaseolus vulgaris L.) ${ }^{1,2}$
}

\author{
Victor H. Ramirez-Builes ${ }^{3}$, Timothy G. Porch ${ }^{4}$ \\ and Eric W. Harmsen 5
}

J. Agric. Univ. P.R. 92(3-4):171-182 (2008)

\begin{abstract}
Plant leaf area is an important physiological trait, and direct, non-destructive methods for estimating leaf area have been shown to be effective while allowing for repeated plant sampling. The objective of this study was to evaluate direct, non-destructive leaflet measurements as predictors of actual leaflet area (LA), to test previously developed models, and to develop genotype-specific linear models for leaflet area estimation in common bean (Phaseolus vulgaris L.). For development of appropriate regression models for leaflet area estimation, four common bean genotypes were evaluated under greenhouse conditions: BAT 477, 'Morales', SER 16, and SER 21. The greenhouse-derived models were evaluated under field conditions. Previously developed models were tested and found to overestimate or underestimate leaflet area. Leaflet measurements included maximum leaflet width $(W)$ and maximum leaflet length $(L)$ and $L \times W$. The measurements with the highest values for the coefficient of determination $\left(R^{2}\right)$ were $W$ or $L \times W$ for BAT 477 , SER 16, and Morales $(0.97,0.95$, and 0.95 , respectively), and $L \times W$ for SER $21\left(R^{2}=0.96\right)$. The linear models developed were shown to be effective and robust for predicting leaflet area under both greenhouse and field conditions during both vegetative and reproductive stages of plant development.
\end{abstract}

Key words: canopy area, legume, leaf length, leaf width

\section{RESUMEN}

Desarrollo de modelos lineales para la determinación del área foliar en habichuela (Phaseolus vulgaris L.) a partir de medidas directas de hojas

${ }^{1}$ Manuscript submitted to Editorial Board 13 December 2007.

${ }^{2}$ This research was supported by the USDA-TSTAR Program (TSTAR-100) and NOAA-CREST. We would like to thank the following individuals for their contributions to this study: Dr. Steve Beebe for providing the germplasm from CIAT (Colombia), and Abraham Montes and Adolfo Quiles for their assistance with the field experiments. We would also like to thank Dr. Ricardo Goenaga (USDA TARS; Mayagüez, P.R.), and Carlos Almodóvar (UPR Agricultural Experiment Station, Juana Díaz, P.R.).

${ }^{3}$ Associate Professor, University of Santa Rosa, Santa Rosa, Colombia.

${ }^{4}$ Research Geneticist, USDA/ARS, Tropical Agricultural Research Station, Mayagüez, P.R.

${ }^{5}$ Professor, Department of Agricultural and Biosystems Engineering, University of Puerto Rico-Mayagüez Campus. 
El área foliar es una medida importante de la fisiología de las plantas, y los métodos indirectos y no-destructivos para medir el área foliar han demostrado ser muy eficientes a la vez que permiten la toma de medidas repetidas en el tiempo. El objetivo del presente estudio fue evaluar directamente métodos no destructivos para la estimación del área foliar en habichuelas (PhaseoIus vulgaris L.) a partir de la medida de las hojas, probar modelos previos, y desarrollar modelos lineales específicos para cada genotipo. Se evaluaron cuatro genotipos: BAT 477, Morales, SER 16, y SER 21, bajo condiciones de invernadero y de campo. Los modelos desarrollados en invernadero se aplicaron y evaluaron bajo condiciones de campo durante dos años. Los modelos previos reportados por otros autores fueron evaluados, y se encontró que sobre- o sub-estimaban el área foliar. Los modelos desarrollados en este estudio incluyeron el ancho máximo de la hoja $(W)$, y la longitud máxima (L), los que fueron empleados para calcular un tercer factor, $L \times W$. Los modelos con mayores coeficientes de determinación $\left(R^{2}\right)$ fueron $W$ o $L \times W$ para BAT 477, SER 16 y Morales $\left(0.97,0.95, y 0.95\right.$, respectivamente) y $L \times W$ para SER $21\left(R^{2}\right.$ $=0.96$ ). Los modelos de regresión desarrollados mostraron ser eficientes en la predicción del área foliar bajo condiciones de campo e invernadero, en las fases vegetativas y reproductivas, para cada uno de los genotipos evaluados.

Palabras clave: área del dosel, leguminosa, longitud de la hoja, ancho de la hoja

\section{INTRODUCTION}

Leaf area (LA) affects light interception, gas exchange, evapotranspiration, and growth rate in plants. Leaf area is often used as an important component in crop modeling (van Oijen et al., 2005; Wallach et al., 2001), as an indicator of crop growth and productivity (Kandiannan et al., 2002), and as a key variable in plant interaction with the atmosphere (Brenner et al., 1995). Although several models are available for leaflet area estimation in bean, these general models have not been compared to genotype-specific models, and triofoliolate and leaflet morphology can vary significantly in $P$. vulgaris.

Leaf area can be determined either directly or indirectly by using destructive or non-destructive methods (Brenner et al., 1995). For directly determining the area of individual leaves, measurements of leaf dimensions or of leaf imaging are used (Marshall, 1968; Yang and Alley, 2005). Indirect determination of LA (e.g., multiband vegetation imaging, plant canopy analysis, and hemispherical photography) is based on factors correlated with leaf area (Strachan et al., 2005). For destructive LA measurements, plants are harvested, leaves are separated, and leaf measurements collected to obtain the leaf area per plant. Alternatively, by using non-destructive methods, plants are left intact and LA is estimated on the basis of calculations from combinations of leaf length (L) and width (W) measurements (Wiersma and Bailey, 1975; Wilhem et al., 2000; Gamper, 2005). This type of estimation has recently been applied to common bean (Bhatt and Chanda, 2003). Non-destructive methods offer the advantage that repeated sampling of the same plant 
can be conducted over time, all of which is especially important when studying genetically segregating populations (De Swart et al., 2004) or plant development. The accuracy of the estimations, however, is dependent on the variation in leaf shape within a single plant, within genotypes, or among genotypes in a species (De Swart et al., 2004).

For a number of species the relationship between leaf dimensions and LA has been sufficiently consistent to allow for the development of mathematical models for LA estimation based on leaf measurements. De Swart et al. (2004) developed several methods for estimating LA in Capsicum; he found that the best model was $\mathrm{LA}=0.690 \times(\mathrm{L} \times \mathrm{W})$. This model was not dependent on plant age or genotype, and thus could be used for LA estimation of different genotypes and of plants at all growth stages. Tsialtas and Maslaris (2005) determined a linear correlation between maximum leaf $\mathrm{W}$ and LA in sugar beet. Using L, Kandiannan et al. (2002) developed allometric models to measure LA of individual leaves in five genotypes of black pepper. Bange et al. (2000) found that the most appropriate model for the relationship between linear dimensions and area of an individual leaf in sunflower included both the $\mathrm{L}$ and $\mathrm{W}$ dimensions, whereas, by using only one dimension, it was possible to estimate LA with considerable time savings (Wiersma and Bailey, 1975).

In common bean, Cintra de Jesus et al. (2001) mentioned an empirical model developed by Iamauti (1995), for measuring LA. Bhatt and Chanda (2003) found in P. vulgaris a linear correlation between leaflet area and the product of length and width and the sum of length and width. The use of leaf area models in common bean was found to reduce sampling effort and cost (Bhatt and Chanda, 2003) and is especially helpful in studies where the leaf area is correlated with other field variables. Leaflet area can subsequently be used for morphological studies or for the estimation of total plant leaf area. However, based on our experience in common bean, variability between cultivars or genotypes results in under- or over-estimation of leaflet area with these general models and may require the development of more specific models.

The objectives of this study were to develop non-destructive, genotype-specific LA estimation models; to compare the previously developed general models with our specific models; and to test the robustness of the genotype-specific models across divergent environments, stages of plant development, and plant densities.

\section{MATERIALS AND METHODS}

Greenhouse experiment. The experiment was conducted at the USDA-ARS Tropical Agriculture Research Station in Mayagüez, 
Puerto Rico $\left(18.2^{\circ} \mathrm{N}\right.$ and $\left.67.13 \mathrm{~W}, 20 \mathrm{masl}\right)$. The greenhouse experiment was planted 23 September 2005 . The average daily temperature was $29.4 / 24.3^{\circ} \mathrm{C}$ (day/night) during the period from planting to harvest. Four common bean ( $P$. vulgaris L.) genotypes were planted, including 'Morales', BAT 477, SER 21 and SER 16. Morales is a small white variety (Beaver and Miklas, 1999) whereas BAT 477, SER 16, and SER 21 are germplasm releases from CIAT (Cali, Colombia). Morales, SER 21 and SER 16 have a type II (erect) and BAT 477 has a type III (prostrate) plant architecture. The seeds were planted in 24 round pots ( 15 $\mathrm{cm} \times 11 \mathrm{~cm}$ ) arranged in a randomized complete block design (RCBD) with four replicates. Sunshine mix \# 1 (Sun Gro Horticulture, Vancouver, British Columbia $)^{6}$ was used as the potting mix; two seeds were planted per pot; the plants were fertilized with Osmocote (14-14-14, N$\mathrm{P}_{2} \mathrm{O}_{5}-\mathrm{K}_{2} \mathrm{O}$ ); and the plants were thinned to one plant per pot one week after planting. Leaflet samples (one leaflet from each trifoliolate) were collected during vegetative and reproductive growth stages: vegetative, $\mathrm{V} 3$, three nodes on the main stem including the primary leaf node; reproductive, R4, pods three inches long, seed not discernible. Twenty randomly selected individual leaflets from 20 plants were selected for measurement during each sampling.

Field experiments. Two field experiments were carried out at the University of Puerto Rico Agricultural Experiment Station at Juana Díaz, Puerto Rico $\left(18^{\circ} \mathrm{N}\right.$ and $66.5^{\circ} \mathrm{W}, 21$ masl $)$. These experiments were planted 3 February 2006 and 17 January 2007. The average daily temperature in 2006 was $28.8 / 19.7^{\circ} \mathrm{C}$ (day/night), and in 2007 was $27.2 /$ $22.9^{\circ} \mathrm{C}$ during the period from planting to harvest. The plants received $472 \mathrm{~mm}$ of water through drip irrigation and rainfall in 2006 and 433 $\mathrm{mm}$ in 2007. Fertilizer (16-4-4, N- $\left.\mathrm{P}_{2} \mathrm{O}_{5}-\mathrm{K}_{2} \mathrm{O}\right)$ was applied at a rate of $628 \mathrm{~kg} / \mathrm{ha}$ and weeds were controlled by cultivation and herbicide application. In both years Morales (13.5 plants $\left./ \mathrm{m}^{2}\right)$ and SER 16 (6.5 plants $/ \mathrm{m}^{2}$ ) were sown, whereas in 2007 SER 21 and BAT 477 were also planted (8.5 plants $/ \mathrm{m}^{2}$ ). Both experiments were arranged in an RCBD, with four replications in 2006 and five replications in 2007. Leaflets were collected on a single day during the vegetative (V) and reproductive $(R)$ growth stages. Twenty-five plants of each genotype and 20 leaflets per plant were randomly selected for measurement at each growth stage.

Leaflet area determination. In the greenhouse trial, actual leaflet area was determined by using the ImageJ (version 1.24) program (Rasband, 1997). ImageJ is a public domain image analysis program

\footnotetext{
${ }^{6}$ Mention of a commercial product does not constitute an endorsement of the product or preference over other products by the authors, or the University of Puerto Rico.
} 
that can be used to determine areas from images by using one or more known measurements and has been used in similar studies (Gamper, 2005). The image program was first tested and found to be accurate by using images with known areas. For actual leaflet area determination, the individual leaf image was captured by using a digital camera, and the individual leaflet area was determined by using ImageJ (Figure 1). For direct leaflet area measurements, maximum $\mathrm{W}(\mathrm{cm})$ and $\mathrm{L}(\mathrm{cm})$ measurements of each leaflet were taken by using a ruler. Length was measured as the distance between the base and the apex of the leaflet; width was measured perpendicular to the length axis at the position on the leaflet yielding the greatest width. Each measurement was fitted to a simple linear regression model and correlation coefficients were estimated. In the field model validation experiment, actual leaflet area was determined by using graph paper. Each leaf was traced onto the graph paper, which was divided into small squares of known area; the number of squares were counted and summed up to obtain the estimate of the total area. The maximum $\mathrm{W}$ and $\mathrm{L}$ were measured with a ruler.

Model development and testing of previous models. The leaflet area data were fitted to single and multiple linear models, and the coefficients of determination $\left(\mathrm{R}^{2}\right)$ and the residual mean squares (RMS) were calculated by using ANOVA (analysis of variance) to evaluate the model's goodness of fit. Model selection and step-wise regression were used to determine the appropriate number of predictors to estimate leaflet area using the coefficient of multiple determination $\left(\mathrm{R}^{2}\right)$ and the number of leaflet measurement predictors (K). Two previously developed general models were also evaluated. To estimate leaflet area in the four genotypes we used the Iamauti (1995) model, LA $=2.1371$ $\left(\mathrm{W}^{1.9642}\right)-2.7013$ (Cintra de Jesus et al., 2001), where $\mathrm{W}$ is the maximum width of the central leaflet of each leaf $(\mathrm{cm})$, and the model LA $=11.98$
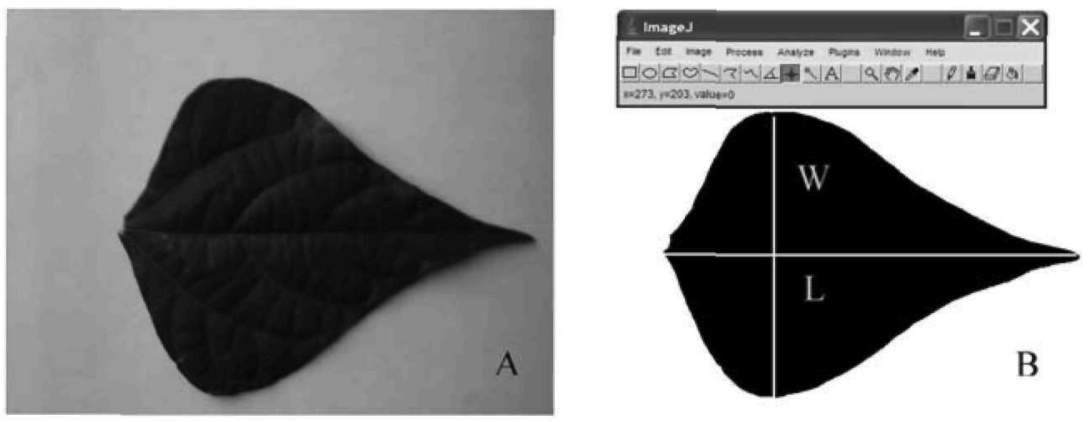

FIGURE 1. Leaflet area analysis using ImageJ. A, Digital image of leaflet; B, Linear dimensions used. 
$+0.06 \mathrm{LW}$ (Bhatt and Chanda, 2003), where L is the leaflet length and $\mathrm{W}$ the leaflet width. The results were compared with the actual leaflet area and the area determined by using the genotype-specific models. The accuracy of LA estimation for all of the models was evaluated by using ANOVA values of RMSE, slope and $\mathrm{R}^{2}$, and the Tukey test. All statistical analyses were completed by using the INFOSTAT Statistical program version 3 (University of Córdoba, Argentina).

\section{RESULTS AND DISCUSSION}

Accurate precise models are needed for the estimation of leaflet area in common bean. Initial application of general common bean models did not yield accurate results; therefore, genotype-specific models were developed and tested in this study and found to be effective and robust.

Genotype-specific model development. In this study, genotypespecific models were developed and high, positive and significant correlations $\left(R^{2}>0.87\right)$ were observed between individual leaflet area (LA) and linear leaflet dimensions (W, L, and $\mathrm{L} \times \mathrm{W}$ ) for the four genotypes tested (Table 1). Higher correlations and RMS were observed between $\mathrm{LA}$ and $\mathrm{W}\left(\mathrm{R}^{2}>0.94\right)$, and $\mathrm{LA}$ and $\mathrm{L} \times \mathrm{W}\left(\mathrm{R}^{2}>0.95\right)$. Leaflet width and $\mathrm{L} \times \mathrm{W}$ gave similar $\mathrm{R}^{2}$ values for BAT 477 , SER 16, and Morales $(0.97$, 0.95 , and 0.95 , respectively); however, $\mathrm{L} \times \mathrm{W}$ was found to have a

TABLE 1.-Results of simple linear regression of leaflet width (W), length $(L)$, and length $\times$ width $(L \times W)$, with actual leaflet area for four greenhouse grown common bean genotypes.

\begin{tabular}{lrcccc}
\hline Genotype & Slope & Intercept & $\mathrm{R}_{\dagger}^{2 \dagger}$ & RMS & p value \\
\hline W & & & & & \\
SER 16 & 9.35 & -20.32 & 0.95 & 12.21 & $<0.001$ \\
SER 21 & 7.80 & -15.99 & 0.94 & 8.52 & $<0.001$ \\
BAT 477 & 10.73 & -29.19 & 0.97 & 25.2 & $<0.001$ \\
Morales & 7.80 & -14.59 & 0.95 & 6.90 & $<0.001$ \\
L & & & & & \\
SER 16 & 6.09 & -23.03 & 0.87 & 32.70 & $<0.001$ \\
SER 21 & 5.93 & -20.41 & 0.92 & 12.16 & $<0.001$ \\
BAT 477 & 9.10 & -42.64 & 0.87 & 93.55 & $<0.001$ \\
Morales & 5.57 & -16.05 & 0.91 & 13.16 & $<0.001$ \\
L $\times$ W & & & & & \\
SER 16 & 0.56 & 1.46 & 0.95 & 14.24 & $<0.001$ \\
SER 21 & 0.53 & 2.28 & 0.96 & 5.08 & $<0.001$ \\
BAT 477 & 0.62 & -0.12 & 0.97 & 19.23 & $<0.001$ \\
Morales & 0.54 & 3.04 & 0.95 & 6.89 & $<0.001$ \\
\hline
\end{tabular}

$\dagger R^{2}$ is the determination coefficient. FMS is the residual mean square. 
higher $\mathrm{R}^{2}$ and lower RMS for SER $21\left(\mathrm{R}^{2}=0.96\right)$. Leaflet length as a single LA predictor exhibited higher RMS and lower $\mathrm{R}^{2}$ values than those with $\mathrm{W}$ and $\mathrm{L} \times \mathrm{W}$; thus, leaflet length is not as accurate a predictor of leaflet area with the genotypes tested.

High correlations between leaf measurements and leaf area have been found previously in bean. Bhatt and Chanda (2003) found an $\mathrm{R}^{2}$ value of 0.74 for $\mathrm{W}, 0.67$ for $\mathrm{L}$, and 0.76 for $\mathrm{L} \times \mathrm{W}(\mathrm{p}=0.01)$ for unspecified bean genotypes. Cintra de Jesus et al. (2001) found an $R^{2}$ value of 0.97 for the relationship between the leaf area index (LAI) and the central leaflet width (W) in the common bean variety Carioca. Thus, leaf measurements are good estimators of LA, and often only single predictors are needed for LA estimation.

Separate linear models were developed for the relationship between leaflet area and $\mathrm{W}, \mathrm{L}$, and $\mathrm{L} \times \mathrm{W}$ for each of the four common bean genotypes. The allometric measures $\mathrm{W}, \mathrm{L}$, and $\mathrm{L} \times \mathrm{W}$ were used to fit multiple linear regression models and the simplest model explaining the largest amount of variance was selected based on an all-subsets-regression procedure through analysis of the relationship between the coefficient of multiple determination $\left(\mathrm{R}^{2}\right)$ and the number of individual leaflet measurement parameters (K) (Figure 2). Single predictors were found to explain almost all of the variance and yielded the simplest models. For BAT 477 (Figure 2a), Morales (Figure 2b), and SER 16 (Figure $2 \mathrm{~d}$ ), $\mathrm{W}$ or $\mathrm{L} \times \mathrm{W}$ were selected, whereas $\mathrm{L} \times \mathrm{W}$ was selected for $\mathrm{SER}$ 21 (Figure 2c). Although two predictors yielded slightly higher $\mathrm{R}^{2}$ values when using the stepwise procedure (data not shown), a simple model, with $\mathrm{W}$ as the single predictor (Table 1), was sufficient for accurate, efficient and precise leaflet area prediction across genotypes. Thus, in this study, $\mathrm{W}$ was selected as the single predictor for leaflet area estimation.

Model validation and comparison with previously developed models. The genotype-specific models, developed from our greenhouse data, were validated with data from field-grown plants in 2006 and 2007. No significant differences were found between mean leaflet area and estimated leaflet area from field data using the $\mathrm{W}$ model developed from the greenhouse study (Table 2). The genotypespecific models were therefore effective for estimating mean leaflet area during both vegetative and reproductive stages, under both greenhouse and field conditions and at different plant densities. Under these variable conditions, no significant differences were observed when using $\mathrm{W}$ as a single predictor; whereas when using $\mathrm{L}$ as a single predictor we observed significant differences for BAT 477 and SER 21.

The genotype-specific models were also compared with previously published models (Iamauti, 1995; Bhatt and Chanda, 2003). The re- 
A
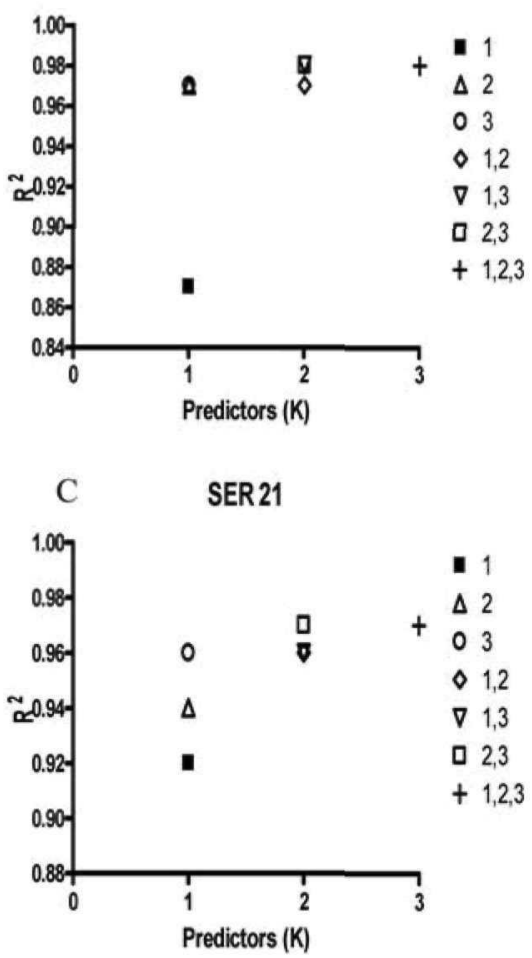
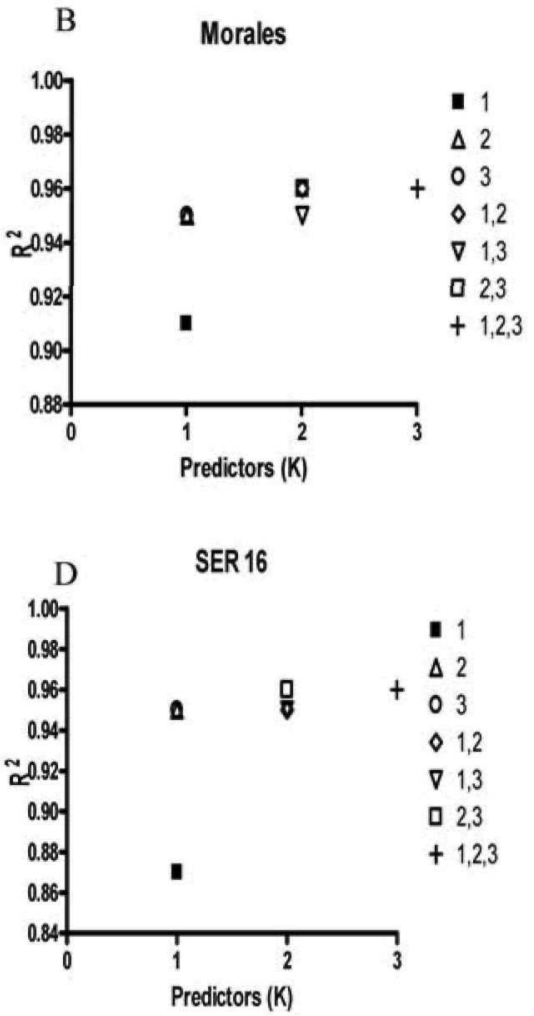

FIGURE 2. Model selection using the plot of the coefficient of multiple determination $\left(\mathrm{R}^{2}\right)$ by the number of leaflet measurement predictors (K) for four (A, BAT 477; B, Morales; C, SER 21; and D, SER 16) greenhouse grown genotypes. (1. L; 2. W; 3. L × W; 1,2. $\mathrm{L}$ and $\mathrm{W} ; 1,3 . \mathrm{L}$ and $\mathrm{L} \times \mathrm{W} ; 2,3 . \mathrm{L} \times \mathrm{W}$ and $\mathrm{W} ; 1,2,3 . \mathrm{L}, \mathrm{W}$ and $\mathrm{L} \times \mathrm{W})$.

sults indicated that Iamauti's model over-estimated leaflet area in all four genotypes used in this study. Bhatt and Chanda's model, on the other hand, under-estimated leaflet area in most cases; however, estimates for Morales and SER16 were not significantly different from mean leaflet area in 2006 (Table 2). Therefore, genotype-specific models may be necessary for effective leaflet area estimation in bean. Additional studies are needed to determine whether race, seed-size, or market class-specific models may yield consistent results given possible similarities in leaflet morphology within these groups of germplasm.

Model robustness. The genotype-specific model based on $\mathrm{W}$ as a single predictor of leaflet area was tested across environments, years, plant densities, and phenological stages and was found to be robust, 
TABLE 2.-Comparison of actual and estimated leaflet area in the field for four genotypes, two years, and two developmental stages using genotype-specific leaflet area models and two previously developed general models.

\begin{tabular}{|c|c|c|c|c|}
\hline \multirow[b]{3}{*}{ Method of calculation } & \multicolumn{4}{|c|}{ Single leaflet area $f \mathrm{~cm}^{2}$} \\
\hline & \multicolumn{4}{|c|}{ V3⿻, 2006} \\
\hline & Morales & SER 16 & SER 21 & BAT 477 \\
\hline Actual & $17.6 \mathrm{ab}( \pm 3.42)$ & $22.9 \mathrm{ab}( \pm 3.3)$ & nd & nd \\
\hline W & $21.1 \mathrm{~b}( \pm 3.8)$ & $27.7 \mathrm{~b}( \pm 6.4)$ & nd & nd \\
\hline L & $18.5 \mathrm{ab}( \pm 4.0)$ & $25.6 \mathrm{ab}( \pm 5.5)$ & nd & nd \\
\hline Iamautti ${ }^{\mathbb{I}}$ & $39.9 \mathrm{c}( \pm 9.1)$ & $58.3 \mathrm{c}( \pm 20.6)$ & nd & nd \\
\hline \multirow[t]{2}{*}{ Bhatt and Chanda ${ }^{\S}$} & $13.7 \mathrm{a}( \pm 0.4)$ & 14.4 a $( \pm 0.22)$ & nd & nd \\
\hline & \multicolumn{4}{|c|}{$\mathrm{R} 3,2006$} \\
\hline Actual & $35.0 \mathrm{ab}( \pm 9.5)$ & $33.8 \mathrm{a}( \pm 9.5)$ & nd & nd \\
\hline W & $35.6 \mathrm{~b}( \pm 9.4)$ & $35.3 \mathrm{a}( \pm 7.8)$ & nd & nd \\
\hline $\mathrm{L}$ & $31.5 \mathrm{ab}( \pm 8.1)$ & $33.4 \mathrm{a}( \pm 7.3)$ & nd & nd \\
\hline Iamautti & $84.6 \mathrm{c}( \pm 31.1)$ & $82.8 \mathrm{c}( \pm 26.2)$ & nd & nd \\
\hline \multirow[t]{2}{*}{ Bhatt and Chanda } & $15.5 \mathrm{a}( \pm 1.2)$ & $15.6 \mathrm{~b}( \pm 1.1)$ & nd & nd \\
\hline & \multicolumn{4}{|c|}{$\mathrm{V} 4,2007$} \\
\hline Actual & $19.0 \mathrm{a}( \pm 5.7)$ & $19.8 \mathrm{a}( \pm 6.9)$ & $20.5 \mathrm{a}( \pm 6.3)$ & $24.5 \mathrm{a}( \pm 7.9)$ \\
\hline W & $20.7 \mathrm{a}( \pm 6.5)$ & $21.8 \mathrm{a}( \pm 6.8)$ & $19.4 \mathrm{a}( \pm 6.8)$ & $29.1 \mathrm{a}( \pm 8.1)$ \\
\hline $\mathrm{L}$ & $19.8 \mathrm{a}( \pm 7.9)$ & $19.0 \mathrm{a}( \pm 7.3)$ & $15.9 \mathrm{~b}( \pm 7.0)$ & $17.1 \mathrm{~b}( \pm 7.6)$ \\
\hline Iamautti & $42.1 \mathrm{c}( \pm 13.9)$ & $42.2 \mathrm{c}( \pm 14.6)$ & $48.5 \mathrm{c}( \pm 16.7)$ & $58.6 \mathrm{c}( \pm 19.4)$ \\
\hline \multirow[t]{2}{*}{ Bhatt and Chanda } & $13.9 \mathrm{~b}( \pm 0.6)$ & $13.9 \mathrm{~b}( \pm 0.5)$ & $13.8 \mathrm{~b}( \pm 0.6)$ & $14.1 \mathrm{~b}( \pm 0.7)$ \\
\hline & \multicolumn{4}{|c|}{$\mathrm{R} 6,2007$} \\
\hline Actual & $22.2 \mathrm{a}( \pm 8.0)$ & $26.4 \mathrm{a}( \pm 5.4)$ & $22.6 \mathrm{ab}( \pm 4.8)$ & $28.9 \mathrm{ab}( \pm 7.2)$ \\
\hline W & $25.9 \mathrm{a}( \pm 6.8)$ & $32.2 \mathrm{ab}( \pm 5.9)$ & $21.3 \mathrm{ab}( \pm 4.3)$ & $35.7 \mathrm{~b}( \pm 10.0)$ \\
\hline $\mathrm{L}$ & $19.5 \mathrm{a}( \pm 6.4)$ & $24.7 \mathrm{~b}( \pm 7.4)$ & $18.4 \mathrm{~b}( \pm 4.2)$ & $20.7 \mathrm{a}( \pm 10.2)$ \\
\hline Iamautti & $53.5 \mathrm{~b}( \pm 22.3)$ & $61.4 \mathrm{c}( \pm 13.5)$ & $57.4 \mathrm{c}( \pm 15.6)$ & $72.3 \mathrm{c}( \pm 22.4)$ \\
\hline Bhatt and Chanda & $14.3 \mathrm{c}( \pm 0.6)$ & $14.5 \mathrm{~d}( \pm 0.80)$ & $14.2 \mathrm{~d}( \pm 0.75)$ & $14.3 \mathrm{~d}( \pm 0.71)$ \\
\hline
\end{tabular}

$\dagger$ Different letters denote significant differences, Tukey test $(\mathrm{P}<0.05)$.

Measured in vegetative and reproductive phases. The values in parentheses represent the standard deviation.

ILA $=2.1371 \times\left(\mathrm{L}^{1.9642}\right)-2.7013$ (Iamautti, 1995); ${ }^{8} \mathrm{LA}=11.98+0.06 \mathrm{~L} \times \mathrm{W}$ (Bhatt and Chanda, 2003).

nd $=$ No data.

(V3 "Three nodes in the main stem including the primary leaf node", V4 "Four nodes in the main stem including the primary leaf node", R3 "Pods $1.3 \mathrm{~cm}$ long at first blossom position" and R6 "Seed at least $0.6 \mathrm{~cm}$ over long axis")

never yielding results significantly different from the actual leaflet area (Table 2). Significant variability was found within genotypes across years in leaflet area (Table 3 ). Thus, there were significant differences both between and within genotypes in leaflet size, yet the models accurately estimated mean leaflet area based on $\mathrm{W}$. The largest differences in leaflet area were those between BAT 477 (type III) and 
TABLE 3.-Comparison of mean leaflet area of four greenhouse-grown genotypes across three environments. $t$

\begin{tabular}{lccc}
\hline & \multicolumn{3}{c}{$\begin{array}{c}\text { Adjusted means for leaf area } \\
\left(\mathrm{cm}^{2}\right)^{\text {t⿱ }}\end{array}$} \\
\cline { 2 - 4 } Genotype & Greenhouse, 2005 & Field, 2006 & Field, 2007 \\
\hline SER 21 & $31.06 \mathrm{a}$ & nd & $21.2 \mathrm{a}$ \\
Morales & $33.19 \mathrm{~b}$ & $26.3 \mathrm{a}$ & $20.6 \mathrm{a}$ \\
SER 16 & $35.10 \mathrm{bc}$ & $28.3 \mathrm{a}$ & $22.0 \mathrm{a}$ \\
BAT 477 & $36.21 \mathrm{e}$ & nd & $26.0 \mathrm{~b}$ \\
\hline
\end{tabular}

$\dagger$ These adjusted means are averages of actual leaflet area collected during the vegetative (V3) and reproductive (R3) growing stages. The covariate is related to the time that leaf area measurements were taken.

†Different letters denote significant differences using Tukey test $(\mathrm{P}<0.05)$ for adjusted means in a covariance analysis.

nd $=$ no data

the other three genotypes (type II) in both greenhouse and field trials (Table 3). Significant variation was also observed in the greenhouse trial between SER 21 (small leaves) and the other three genotypes. Leaflet area also changed with phenology, from vegetative to reproductive growth phases for Morales and SER 16 in the field and greenhouse; this change was due to changes in both leaflet length and width (Figure 3). Notwithstanding this variability, $\mathrm{R}^{2}$ values of $>0.89$ were found in a regression analysis of estimated versus actual LA by using combined field data from 2006 and 2007 (Figure 3). The variation in leaflet size due to variable environmental conditions did not significantly affect the accuracy of leaflet area estimation, thus indicating that the genotype-specific models are robust when using $\mathrm{W}$ as a unique predictor.

Linear dimensions were shown to be reliable parameters for generating leaflet area estimates, thus indicating that the relationship between leaflet width and leaflet area is fairly stable across environmental conditions. Genotype-specific models appear to be more accurate than general models in common bean for leaflet area estimation; however, other groupings (such as by common bean race, seed size or market class) may also be effective.

\section{CONCLUSIONS}

This study has shown the effectiveness of individual leaflet measurements for the estimation of individual leaflet area in four bean genotypes. Using a direct, non-destructive technique allowed multiple sampling at different phenological stages. The results indicated that 

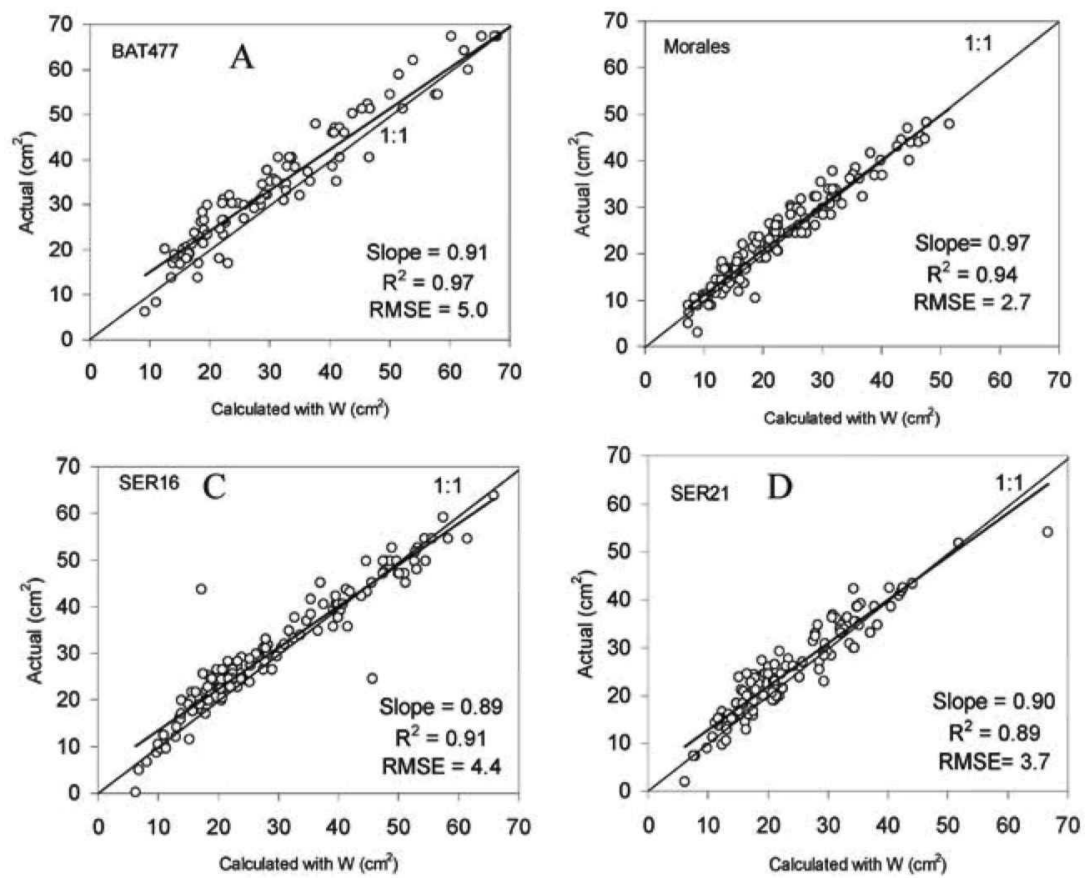

FIGURE 3. Model validation using regression analysis on combined data from the 2006-2007 field trials with $W$ as a single predictor (A, BAT 477; B, Morales; C, SER 16; and D, SER 21).

the single predictor, leaflet width, was sufficient for single leaflet area estimation, that genotype-specific leaflet area models for four genotypes were robust across environments and physiological stages, and that genotype-specific models may often be necessary in predictions with common bean.

\section{LITERATURE CITED}

Bange, M. P., L. G. Hammer, P. S. Milroy and G. K. Rickert, 2000. Improving estimates of individual leaf area of sunflower. Agron. J. 92:761-765.

Beaver, J. S. and P. N. Miklas, 1999. Registration of Morales small white bean. Crop. Sci. 39:1257.

Bhatt, M. and S.V. Chanda, 2003. Prediction of leaf area in Phaseolus vulgaris by non-destructive method. Bulg. J. Plant Physiol. 29:96-100.

Brenner, A. J., M. Cueto Romero, J. García Haro, M. A. Gilabert, L. D. Incoll, J. Martínez Fernández, E. Porter, F. I. Pugnaire and M. T. Younis, 1995. A comparison of direct and indirect methods for measuring leaf and surface areas of individual bushes. Plant Cell Environ. 18:1332-1340. 
Cintra de Jesus, W., F. X. Ribeiro do Vale Jr., C. R. Resende and C. L. Costa, 2001. Comparison of two methods for estimating leaf area index on common bean. Agron. J. 93:989-991.

De Swart, A. M., R. Groenwold, H. J. Kanne, P. Stam, L. F. M. Marcelis and R. E. Voorrips, 2004. Non-destructive estimation of leaf area for different plant ages and accessions of Capsicum annuum L. J. Hortic. Sci. Biotechnol. 79:764-770.

Gamper, H., 2005. Nondestructive estimates of leaf area in white clover using predictive formulae. Crop Sci. 45:2552-2556.

Iamauti, 1995. Avaliacao de danos causados por Uromyces appendiculatus no feijoeiro. Escola Superior de Agricultura Luiz de Queiroz, Piracicaba, SP (Brazil). 1995. 85 p.

InfoStat, 2003. InfoStat, version 3. User Manual. Infostat Group, FCA, Universidad Nacional de Cordoba, Argentina. http://infostat.com.ar

Kandiannan, K., C. Kailasam., K. K. Chandaragiri and N. Sankaran, 2002. Allometric model for leaf area estimation in black pepper (Piper nigrum L.). J. Agron. \& Crop Sci. 188:138-140.

Marshall, J. K., 1968. Methods for leaf area measurement of large and small leaf samples. Photosynthetica 2(1):41-47.

Rasband, W. S., 1997. ImageJ. U.S. National Institutes of Health, Bethesda, Maryland, USA, http://rsb.info.nih.gov/ij/, last revised 2006.

Strachan, L. B., D. W. Stewart and A. Pattey, 2005. Determination of leaf area index in agricultural systems. p. 179-198. In: J. L. Hatfield and J. M. Baker (Ed.) Micrometeorology in agricultural systems. Monograph 47. ASA, CSSA, SSSA, Madison, WI, USA.

Tsialtas, J. and N. Maslaris, 2005. Leaf area estimation in a sugar beet cultivar by linear models. Photosynthetica 43:477-479.

Van Oijen, M., M. Hoglind, M. H. Hanslin and C. Caldwell, 2005. Process-based modeling of timothy regrowth. Agron J. 97:1295-1303.

Wallach, D., B. Goffinet, J. E. Bergez, P. Debaeke, D. Leenhardt and J. N. Aubertot, 2001. Parameter estimation for crop models: A new approach and application to a corn model. Agron. J. 93:757-766.

Wiersma, J. V. and T. B. Bailey, 1975. Estimation of leaflet, trifoliolate, and total leaf areas of soybeans. Agron. J. 67:26-30.

Wilhelm, W. W., K. Ruwe and M. R. Schlemmer, 2000. Comparison of three leaf area index meters in a corn canopy. Crop Sci. 40:1179-1183.

Yang, J. and M. Alley, 2005. A mechanistic model for describing corn plant leaf area distribution. Agron. J. 97:41-48. 